\title{
Domination Of Female Microfinance Clients In Pakistan
}

\author{
Shafiq-ur-Rehman \\ Rizwana Bashir \\ \& \\ Adeela Sajjad \\ Department of Economics \\ University of Karachi
}

\begin{abstract}
Microfinance has been recognized and proven as a most admired option to combat poverty in Pakistan. But another characteristic of microfinance which has become obvious is its greater inclination towards female clients. Through this study it is observed that a large number of microfinance providers (MFPs) give preference to female clients over male clients due to certain reasons. The overall aim of this paper is to explore the extent of gender biases by MFPs and finding out possible reasons responsible for gender biasness. MFPs in Pakistan are either operating with profit motive or with poverty alleviation motive. The reasons for female orientation reported by MFPs operating for profit motive are their dedication, hard working and commitment to make their business venture a success and also to repay their debts on time. Other MFPs operating with poverty alleviation motive give preference to female clients because females are considered to be the most deprived and less privileged segment of the society. This study also examines the long term effects of gender biasness by MFPs. It is feared that the current greater inclination towards female clients may result into their exclusion in the long term which may not be a favourable situation.
\end{abstract}

\section{تلخيصِ مقالم}

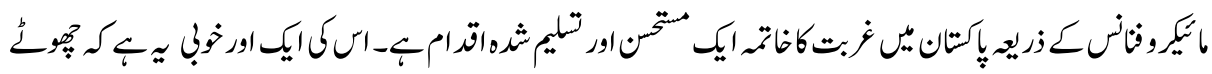

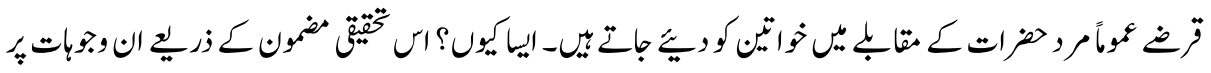

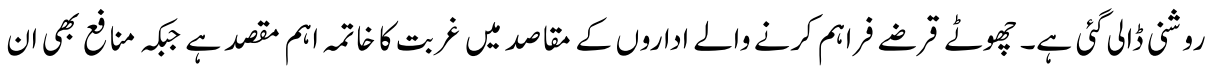

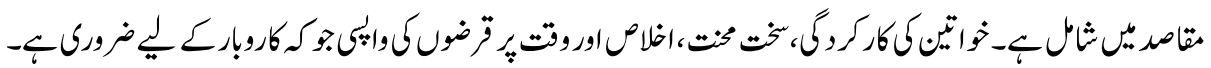

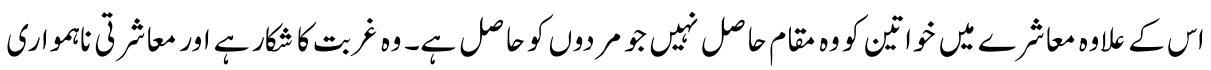

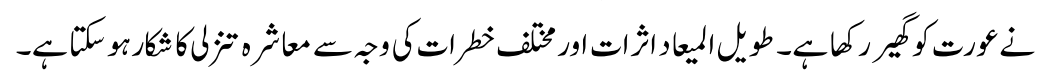

Keywords: Microfinance, empowerment of women, poverty alleviation, Gender biasness. 


\section{Introduction}

The recent acknowledgement and attentiveness towards microfinance is the result of many government and non government experiments to alleviate poverty, but the results are often disappointing. The results are affected by corruption or the assistance aids (in the form of subsidies or donations) create dependency and discouragement.

When poverty is not addressed seriously and promptly, it may cause serious impression on socio-economic structure of the society. When poor is denied of access to his basic rights, such as, justice, education, employment, health, shelter, etc., he could turn into a burning flame. To meet his emergencies, he commits crime. When the degree of poverty rises, together with illiteracy rate, propensity of crime also increases resulting in socioeconomic unrest in the country. Microfinance institutions seem to have found a sustainable solution to the problem of poverty. In the mid 1980s, inspired by the Raiffeisen cooperative model development in Germany in 1964, the Grameen Bank in Bangladesh and other replicates have been lending to the poor people with loan repayment rate above 95 percent. Today, these microfinance programs serve 10 million households and have been set up in Africa, Asia, Latin America and US.

As South Asia hosts the largest population of the poor-about half the world's total. What clearly emerges from the discussion is that South Asia seems to be the most sensitive area and is also the strongest candidate to be examined in terms of poverty alleviation. UNDP has tried to go beyond the indicator of poverty line and developed an even broader index as a measure of well being i.e. Human Development Index (HDI) as part of Human Development Report (HDR). The HDI gives a collective measure of three dimensions of human development: in terms of life expectancy, educational attainment and adjusted real income. It focuses on living a long and healthy life (measured by life expectancy), being educated (measured by adult literacy and gross enrolment ratio in education) and having an upright standard of living (measured by purchasing power parity, PPP, income). Hence this discussion will catch Pakistan (a South Asian country which rank 141st on an index of 182 countries worldwide) as a sound case study to be examined.

The phenomenon of deliberate gender biasness towards females is global practice of MFPs for several reasons but highly controversial at the same time. Women are preferred for their good repayment by most MFPs with commercial focus and they are equally given preference by other MFPs having poverty alleviation focus for women being most deprived and underprivileged segment of the society. There is a fear that the recent high focus may lead to their exclusion in the long run and in that case it will not be a favorable situation.

The most imperative rationale for this exclusion is that a good repayment does not guarantee profitability. Profitability leads to financial stability of MFP. There is another 
argument about gender biasness that targeting women is indeed more costly for diverse reasons. They borrow smaller amounts, they are novice, have less exposure and mostly poor women are not educated, and they necessitate supplementary services (healthcare, training etc.) and sometimes additional supervision. Therefore, a focus on women takes the financial performance of an MFP beyond repayment rates. The optimistic repayment experience associated with a focus on women is offset by elevated costs related to smaller amounts of loans. Though the role of women in society is very important and it depicts the potential for development in a nation. Specially, a country like Pakistan having around 50 percent female population can not move towards growth and prosperity without empowering its women. Studies show that when women are given access to financial services it does improve their living. In the current research study the client profiles of MFPs in Pakistan are examined in terms of male / female client ratio and conclusions are drawn on the basis of current profiles and their long term effects.

\section{Review of Literature}

\section{Poverty-An Overview}

World Bank (1995) reported that poverty was a multidimensional issue. One key dimension was the consumption poverty -the degree to which actual levels of private consumption of households or individuals fall below a "poverty line" that society believes a minimum adequate standard of private consumption.

Musharaf (2002) says that Pakistan is well aware of the challenges poverty poses to humanity. Inequalities between the richest and the poorest communities are widening. Women are worst hit by poverty, and with them the family unit gets entangled in a vicious cycle of poverty, ignorance, diseases and even more poverty. Action is required on a number of fronts, as only a multi-pronged strategy can deal with the dilemma of poverty.

Yunus (2006) said that poverty is not something created by the poor people. Poverty is the outcome of the society's way of life. One good example in the context would be the welfare system of USA. The said system is designed to keep people in poverty rather than take them out of it. We should be endeavoring at creating poverty museums where children will go to visit to find how poverty used to be. We have now an environment where 100 percent of the children of Grameen borrowers are in school, not only they are in school; they are graduating - going to college. Many of them are becoming professionals, doctors, engineers though they are children of illiterate borrowers. The poor themselves can create a poverty-free world; all we have to do is to release them from the chains that we have put around them. Grameen too believed in giving more preference to female borrowers because empowering female facilitate the entire family in improving the life style and coming out of poverty. 
Situation of poverty is horrible in Pakistan as well. According to the latest Human Development Report of UNDP (2009), Pakistan ranked at 101st on human poverty index out of 182 countries with poverty level of $33.4 \%$ and it ranks at 141 st on human development index. It indicates that percentage of people living below poverty line has increased and the current status communicates dire need to address the problem of poverty on emergency basis.

\section{Microfinance-An Overview}

The concept of microfinance emerges from Adam Smith's famous saying that 'Money creates more money'. It is often easy to get more money when you got a little. Microfinance, as the term implies, refers to providing small loans to the low-income clients living in both urban and rural areas to kick-start a business in the informal sector. Providers of microfinance may include formal-sector institutions (such as, microfinance banks); semiformal bodies such as non-government organizations (NGOs). Over the last ten years, successful experiences in providing finance to small entrepreneur and producers demonstrate that poor people, when given access to financial services at market rates, repay their loans and use the proceeds to increase their income and assets. State Bank of Pakistan (2005) in its report recognized microfinance as a substitute for informal sources of financing which requires no security.

\section{Microfinance as an Anti-Poverty Strategy}

Microfinance has proven itself as an anti-poverty strategy globally. For example Yunus (2006), claims that 58\% of the poor who borrowed from Grameen are now out of poverty. There are over 100 million people now involved with micro-credit programs. Microfinance is a local process and based on local institutions that collect local resources and recollect them locally.

In Pakistan, microfinance is gaining importance as an effective tool of social mobilization and poverty alleviation. The major objectives, of micro credit schemes are to reduce poverty through empowerment of poor people specially the women by providing them less costly loans and creating employment opportunities. Currently in Pakistan, a variety of institutions ranging from NGOs to private and government sponsored rural support programs are delivering microfinance services to the poor. However, the microfinance service market in Pakistan remains underdeveloped and serves only 7 to 8 per cent of these potential clients. If microfinance is to serve a large share of the market, practitioners must improve their programs by enhancing their outreach access to the potential clients. Microfinance is helpful in reducing poverty by providing the poor with credit facility to start or expand the small business. It not only supports the economic condition of the poor people but also has positive impacts on their social life through 
better standard of living with greater access to education and health facilities and empowerment to participate in decisions of the society.

\section{Microfinance in Pakistan}

The microfinance program has been functioning in Pakistan in one form or the other since 1970s. It was first launched by the then government to attack poverty. According to Pakistan Microfinance Network (PMN) microfinance providers in Pakistan are classified into four categories. This included Microfinance Banks (MFBs), Microfinance Institutions (MFIs), Rural Support Programs (RSPs) and others including NGOs and commercial financial institutions. Realizing the need and importance of microfinance, as a tool of poverty reduction and social mobilization, the government has accelerated its efforts to establish strong foundations of microfinance in formal sector and extended considerable support to the informal sector (NGOs) as well.

Then Microfinance Institutions (MFI) Ordinance 2001 was put in place to provide a separate regulatory framework for microfinance sector. The Microfinance Institutional Framework currently supports one million active borrowers, which are intended to be increased to 3 million by 2010 .

As awareness about the MFIs framework grows, variety of microfinance institutions are likely to be established in the foreseeable future. Microfinance operators working in Pakistan as classified by Pakistan Microfinance Network (PMN) into four distinct groups necessitate some explanation as under:

\section{MFBs}

Microfinance Bank licensed and prudentially regulated by the State Bank of Pakistan to exclusively service microfinance market. MFBs include following; Khushhali Bank (KB), Network MicroFinance Bank Ltd. (NMFB), Pak-Oman Microfinance Bank Ltd. (POMFB), Rozgar Microfinance Bank Ltd. (RMFB), Tameer Microfinance Bank Ltd. (TMFB), The First MicroFinanceBank Ltd. (FMFB).

\section{MFIs}

Microfinance institution providing specialized microfinance services include; Akhuwat, Asasah, Kashf Foundation, Orangi Pilot Project (OPP), Sindh Agricultural and Forestry Workers Cooperative Organization (SAFWCO), Community Support Concern (CSC), Development Action for Mobilization and Emancipation (DAMEN). 


\section{RSPs}

These programs are running microfinance operations as a division of their multidimensional rural development program. These include the following; Lachi Poverty Reduction Project (LPRP), National Rural Support Programme (NRSP), Punjab Rural Support Programme (PRSP), Sarhad Rural Support Programme (SRSP), Thardeep Rural Development Programme (TRDP).

\section{Others}

All institutions that do not fall within above three categories. These are financial institutions in the conventional financial sector, providing microfinance services as a separate function within the broader organizational context. These mostly include CFIs and NGOs. For example;

ORIX Leasing Pakistan Ltd. (OLP), Jinnah Welfare Society (JWS), Narowal Rural Development Programme (NRDP), Organization for Participatory Development (OPD), Rural Community Development Society (RCDS), Save the Poor (STP), Sindh Rural Support Program (SRSP), Sungi Development Foundation (SDF), Swabi Women's Welfare Society (SWWS), Taraqee Foundation (TF).

\section{Microfinance: A Tool of Development}

Although microfinance is not a new concept, the current popularity of microfinance has its beginning in 1976 when world famous economist Muhammad Yunus initiated providing small amounts of cash (micro-credit) to rural women in Bangladesh to start or expand their business. Dr. Yunus found the experiment of women empowerment through microfinance very successful. The beneficiaries of these small loans repaid them on time and ran successful ventures; this in turn encouraged Dr. Yunus to expand his lending program which has become the famous Grameen Bank now. Since 1976, Grameen has handed out 3.12 million borrowers and disbursed \$4.18 billion loans. (Yunus, 2004)

The target clientele for microfinance services include female heads of households, pensioners, displaced persons, retrenched workers, small farmers, and microentrepreneurs, each of whom falls into one of four poverty levels: destitute, extreme poor, moderate poor and vulnerable non-poor. With the geographic expansion of microfinance has come an explosion of organizations providing credit to the poor.

Within the cadre of organizations and non-governmental organizations (NGOs) who support, fund, or deliver microfinance services, several trends are evident. These include an increasing focus on savings mobilization, a broadening of acceptable loan use from solely income-generating purposes (e.g. micro-enterprises) to consumer purposes (e.g. education and health needs), a shifting of focus from credit provision to institutional 
sustainability and financial intermediation, and the extension of the scale and depth of microfinance institutions (MFIs). In short, the financial systems approach is becoming the dominant paradigm in the microfinance world - or at least seems to be gripping the bulk of the ink being spilled in the movement.

\section{Microfinance and Women Empowerment}

In past many success stories witness poverty alleviation through women empowerment globally. Researchers have thrown light on positive and negative both aspects of increased women preference by MFPs worldwide.

Grasmuck and Espinal (2000) researched and found that providing women with access to credit can twist the entire economy and proved that it is always more beneficial to provide credit to women than to men. He most significantly reasoned that when a woman's enterprise succeeds and she makes a profit, it all goes to her family, while men in general give only 50-70 percent of their income to their families.

Cheston and Kuhn (2002) believe that the exceptional practice of microfinance is its almost exclusive focus on women. They also discovered in their study of poverty profiles of various countries that the countries in which women are exploited or treated as second class citizens are found in high rate of poverty and also women were found in the majority of poor population in these countries. This fact was further confirmed by a World Bank report that gender discrimination cost a nation in terms of increasing poverty, sluggish economic growth, bad governance, and a lower livelihood of their people.

Swope (2005) recognized microfinance as potentially harmful to women stating that it may lead to domestic abuse may result from husbands jealous of their wives' financial power. Evidences reveal that microfinance can lead to a raise in income, improved nutrition for families, improved school attendance, empowering the women, and finally leading to poverty alleviation.

\section{Research Methodology}

In this research, methodology includes primary as well as secondary data analysis. For collection of primary data research tool used is questionnaire and it covers the data collection period of 2006 to 2008. Equal importance is given to qualitative and quantitative data both. Secondary data analysis and case histories were used in the early stages. A variety of sources were helpful for gathering secondary data including various international reports issued by United Nations, Economic Surveys of Pakistan and various periodic publication of Pakistan Microfinance Network. Secondary data analysis was helpful in connecting what has been done earlier and findings of the current research. The selected sampling procedure is quota Sampling. The sample is collected from all four 
types of MFPs operating in Pakistan as classified by PMN, so that participation of all categories of MFPs could be ensured to make the scope of the research comprehensive. We know that Microfinance Banks (MFBs), Microfinance Institutes (MFIs), Rural Support Programmes (RSPs) and others all have different scope, different clientele, and different objectives. In this view it was important to have representation of all of these four categories in the sample extracted from them.

\section{Are MFPs Micro Financing Women? Facts and Analysis}

\section{Facts and Analysis}

Table 4.1 summarizes the responses received from sampled microfinance providers displaying percentages of male and female clients of each MFP and also the male/female client ratio category wise i.e. Rural Support Programs (RSPs), Microfinance Institutions (MFIs), Microfinance Banks (MFBs) and others.

Table 4.1 Male/Female Client Ratio of MFPs

\begin{tabular}{|c|c|c|c|}
\hline $\begin{array}{c}\text { MFP } \\
\text { Category }\end{array}$ & MFPs & $\begin{array}{l}\text { Percentage of } \\
\text { Male Clients }\end{array}$ & $\begin{array}{c}\text { Percentage of } \\
\text { Female Clients }\end{array}$ \\
\hline \multirow[t]{2}{*}{ RSP } & SRSP & 49 & 51 \\
\hline & NRSP & 59 & 41 \\
\hline \multicolumn{2}{|c|}{ Total } & 54 & 46 \\
\hline \multirow[t]{2}{*}{ MFI } & KASHAF & 1 & 99 \\
\hline & ASASAH & 0 & 100 \\
\hline \multicolumn{2}{|c|}{ Total } & 0.5 & 99.5 \\
\hline \multirow[t]{2}{*}{ MFB } & FMFBL & 63 & 37 \\
\hline & KHUSHAL & 81 & 19 \\
\hline \multicolumn{2}{|c|}{ Total } & 72 & 28 \\
\hline \multirow[t]{3}{*}{ Others } & ORIX & 12 & 88 \\
\hline & JWS & 22 & 78 \\
\hline & TF & 49 & 51 \\
\hline \multicolumn{2}{|c|}{ Total } & 27.7 & 72.3 \\
\hline \multicolumn{2}{|c|}{ Overall Ratio of } & 37 & 63 \\
\hline
\end{tabular}

Source: Computed

The data on total number of clients is gathered as ratio between two sub divisions i.e. male clients and female clients. Many research studies highlight that the purpose of microfinance is to empower poor specially the women. As women are generally deprived from financial resources regardless they are held responsible for household duties. Giving power to women strengthens the family. Women are generally regarded as hard working, committed and generate results early as compared to male clients and also repay their 
loans on time. For these vary reasons currently MFPs in Pakistan are also having a preference for female clients over the male clients. Figure 4.1 indicate the Male/Female Client Ratio of MFPs in Pakistan depicted from Table 4.1.

Figure 4.1 Male/Female Client Ratio of MFPs

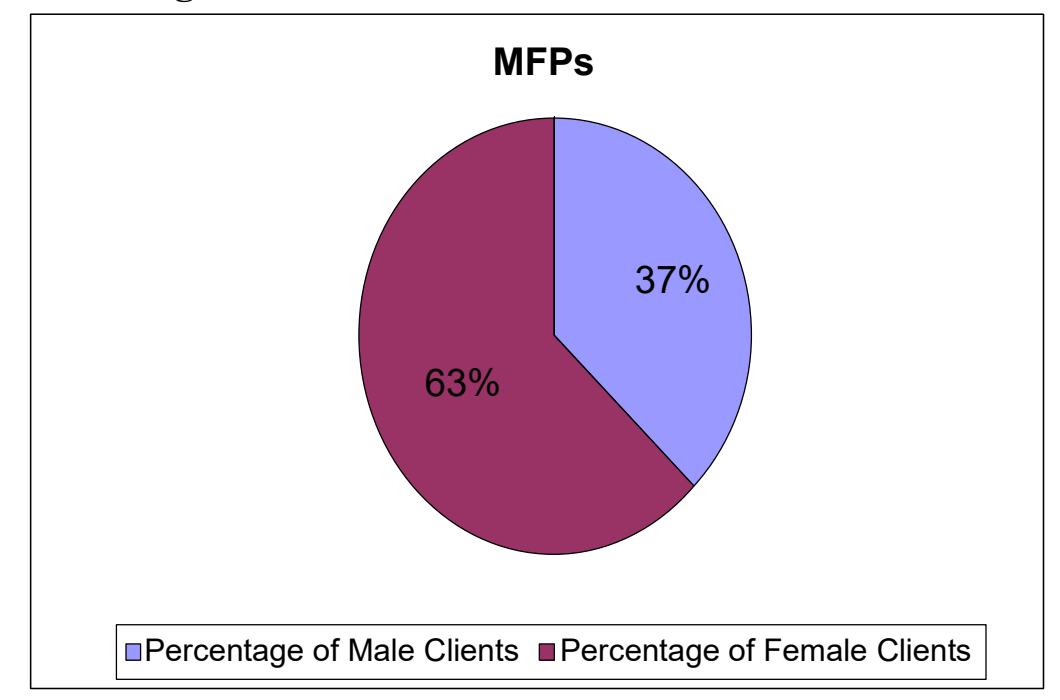

Source: Computed

Through this study it was revealed that even some MFPs do not have any male client and their 100 percent focus is towards female clients. From the total borrowers of MFPs on average currently 63 percent are female clients and 37 percent are male clients. As highlighted before a greater focus on female clients demonstrates an intention of MFPs to reach the core poor because women are categorized to be the most underprivileged in the society.

Figure 4.2 Male/Female Client Ratio of Sampled MFPs

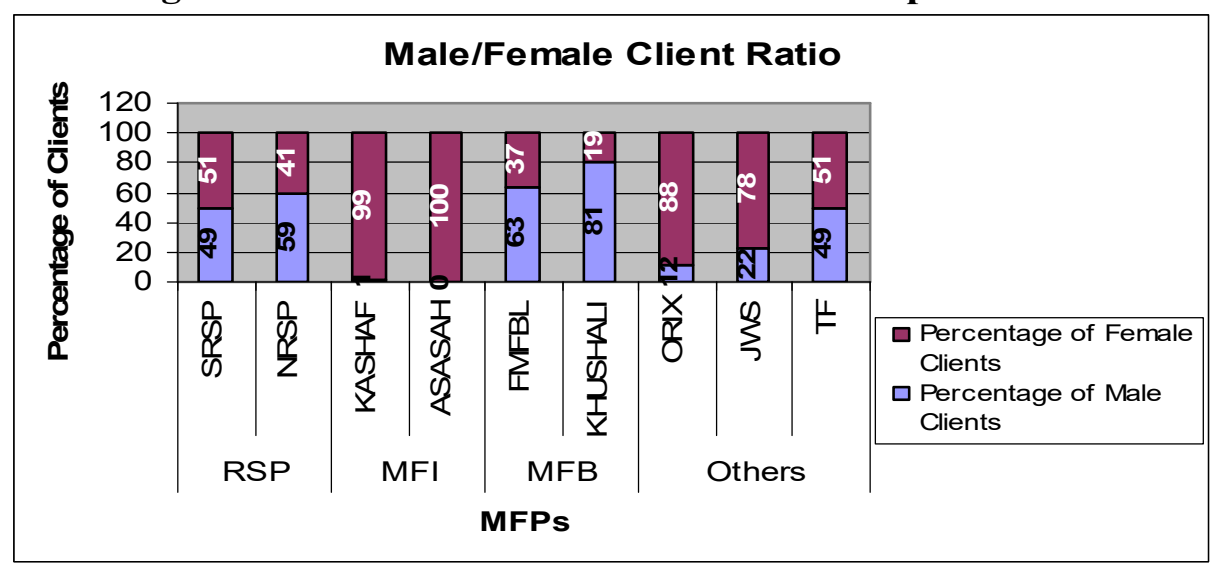

Source: Computed 
Male/Female client ratio of sampled MFPs as shown graphically in Figure 4.2 also indicates their greater inclination towards females. ASASAH is an MFI with 100 percent female clients. They do not offer financial services to male clients. KASHF has only 1 percent male clients and 99 percent female clients. ORIX a commercial Financial Institution (CFI) offer microfinance services to 88 percent female clients and only 12 percent male clients. Jinnah Welfare Society (JWS) has 78 percent female clients and 22 percent male clients. Taraqi Foundation (TF) has 51 percent female clients and 49 percent male clients. Sarhad Rural Support Programme (SRSP) also has 51 percent female clients and 49 percent male clients. National Rural Support Programme (NRSP) show its larger focus on male clients that is 59 percent and less female clients they are only 41 percent. Both MFBs taken in the sample show more focus on male clients over females. FMFBL has 63 percent male clients and 37 percent female clients. KHUSHALI has 81 percent male clients and only 19 percent female clients. Out of nine sampled MFPs, six have greater focus on female clients and only three prefer microfinancing with male clients.

We can also analyze male/female ratio category-wise to evaluate further that what type of MFP focuses on male clients and which category of MFPs prefer to microfinance with female clients. The 'others' category consisting on NGOs and CFIs displayed 72 percent female client and only 28 percent male clients. Figure 4.3 displays graphically the male/female client ratio of 'others' category. This category of MFPs is the largest in size in Pakistan amongst all types of microfinance service providers therefore it can be said that if they are having above 70 percent female borrowers then overall as an industry also there will be greater proportion of female clients as compared to male clients. This fact is already mentioned in Figure 4.1. The basis for this attention towards female clients as previously mentioned is there hard work, perseverance and determination to pay off the debts on time.

Figure 4.3 Male/Female Client Ratio of 'Others' Category

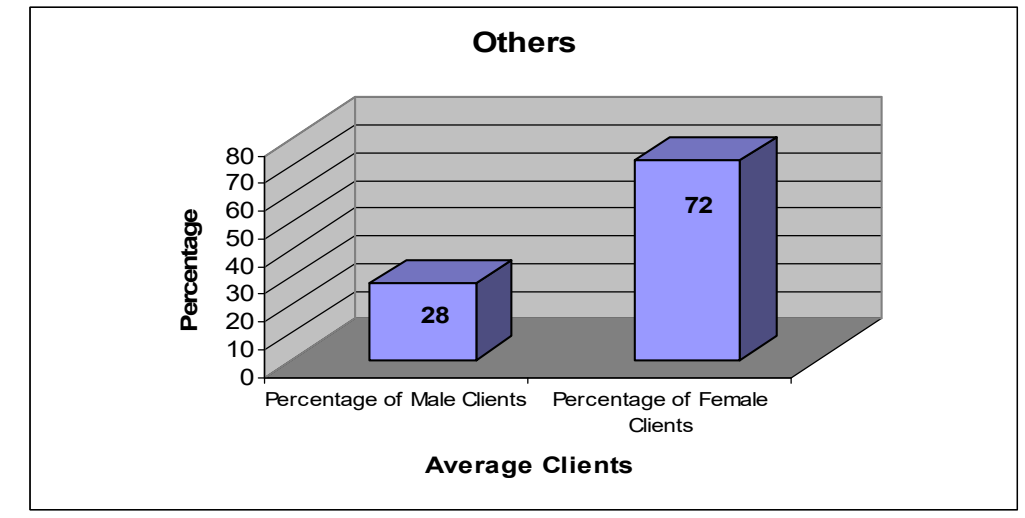

Source: Computed 
As we have observed in figure 4.3 NGOs and CFIs have greater focus towards female clients we can also witness in Figure 4.4 that 'MFIs' also have much larger concentration towards lending micro loans to female clients for the same reasons mentioned earlier. MFIs have 99.5 percent female clients whereas only 0.5 percent male clients. MFIs in Pakistan largely experienced it to be more feasible to provide microfinance service to female clients not the male clients.

Figure 4.4 Male/Female Client Ratio of 'MFIs' Category

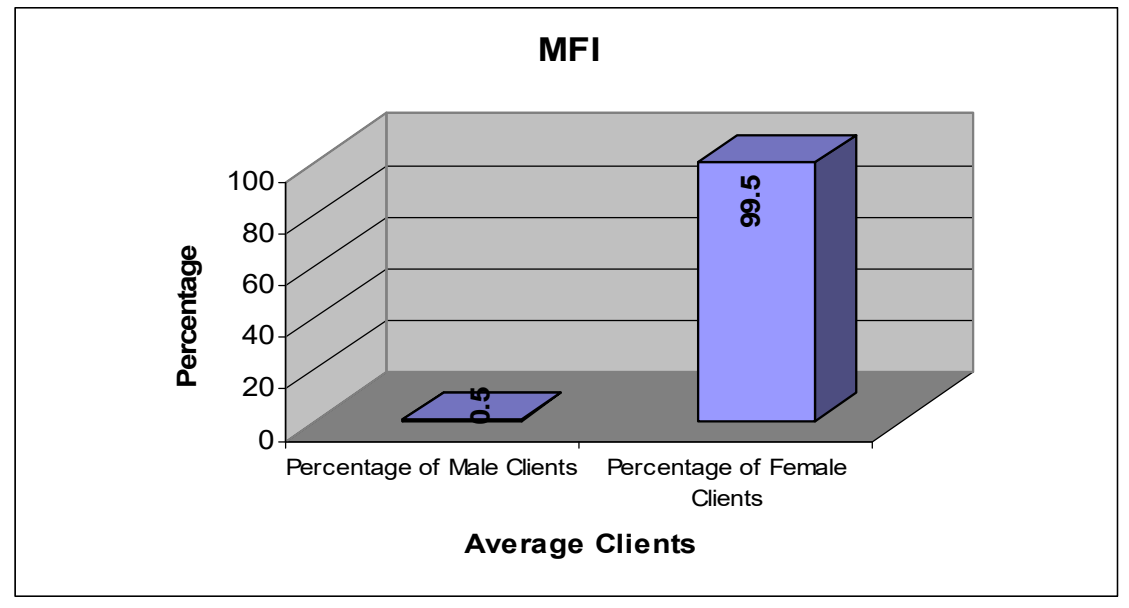

Source: Computed

Amongst all four categories of MFPs there are two types of MFPs in Pakistan with larger attention towards male clients. These are 'MFBs' and 'RSPs'. As exhibited in Figure 4.5 'MFBs' are having more male borrowers and less female borrowers. MFBs have currently 72 percent male clients to whom they are offering microfinance service as compared to only 28 percent female client.

Figure 4.5 Male/Female Client Ratio of 'MFBs' Category

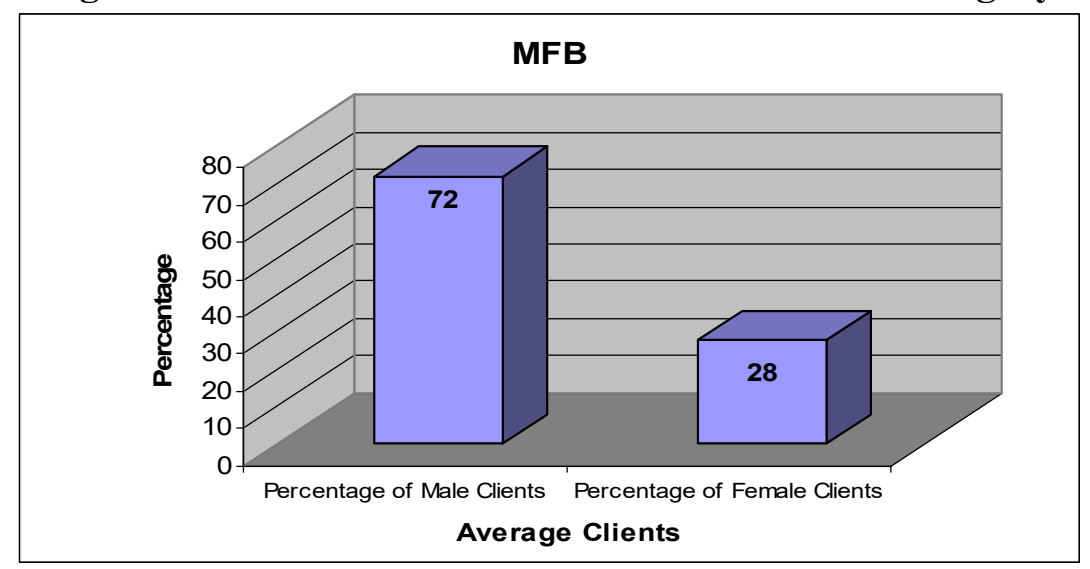

Source: Computed 
Figure 4.6 display male/female client ratio of 'RSPs' graphically with the larger bar of male clients and the smaller for female clients. Though the difference is not big. RSPs currently have 8 percent more male clients then there female clients. There are 54 percent male clients and 46 percent female clients of RSPs. It shows that various RSPs have also not ignored female borrowers rather kept the ratio almost balanced.

Figure 4.6 Male/Female Client Ratio of 'RSPs' Category

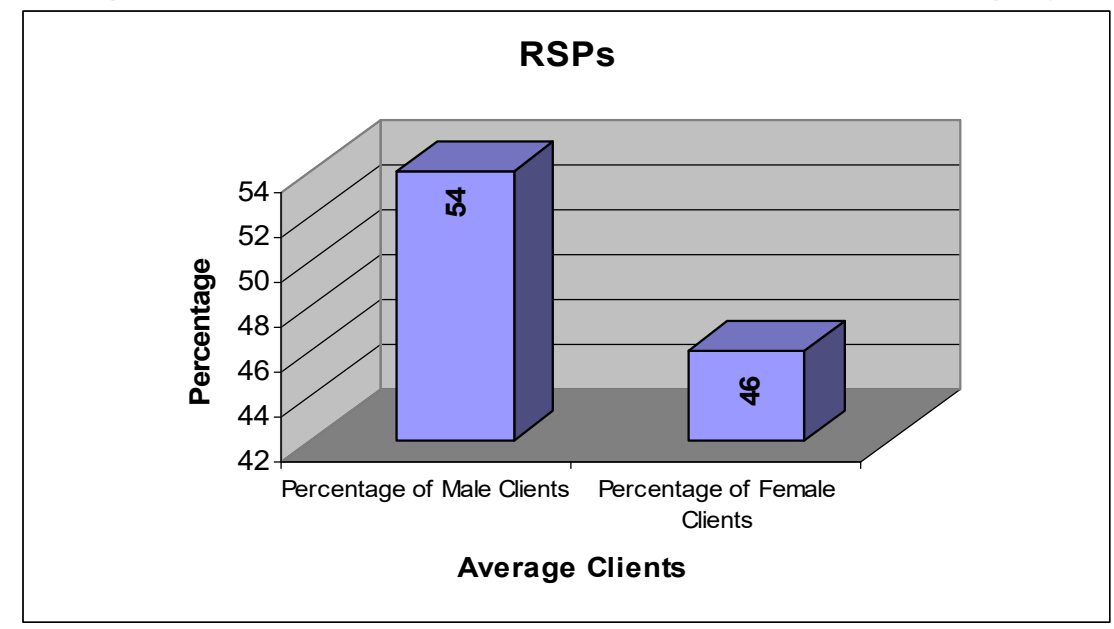

Source: Computed

Through an analysis of Male/Female focus by MFPs in Pakistan we can also find out their success in reaching the core poor for poverty alleviation purpose because women are characterized as the most deprived or the poorest segment of society.

\section{Conclusion}

Through this study it was revealed that even some MFPs do not have any male client and their 100 percent client focus is towards female clients. The bases for the current concentration of microfinance providers towards female clients are obvious through their own experiences worldwide. Traits like hard work, perseverance and determination to pay off the debts on time make women superior amongst the clients of MFPs. But banks are also concerned with cost of managing the loan therefore they may find it expensive to lend micro loans to women and find feasible to offer microfinance to male clients to be profitable themselves in the long run. There is no doubt in acknowledging the positive role of microfinance in women's lives. In some cases women have significantly changed their lives towards betterment and earned respect and status in the society through microfinance. This empowered status also resulted in a decline in domestic violence on women. In the long run the current female focus can be continued only if MFPs remain sustainable themselves in doing so. 


\section{References}

Adams, Richard (2003), Economic Growth, Inequality and Poverty: Findings from a New Dataset, World Bank's Poverty Reduction Network. http://info.worldbank.org/ etools/BSPAN/PresentationView.asp?EID=399\&PID=783

Cheston, Susy and Lisa Kuhn (2002) Empowering Women Through Microfinance. In Sam Daley-Harris, Ed. Microcredit Summit Campaign. Pathways Out of Poverty. Kumarian: Bloomfield, CT.

Government of Pakistan (2005), Economic Survey of Pakistan, Ministry of Finance, Islamabad, p. 2.

Government of Pakistan (2007), Economic Survey of Pakistan, Ministry of Finance, Islamabad, p. 62-63.

Government of Pakistan (2007), Economic Survey of Pakistan, Ministry of Finance, Islamabad, p. 18-31

Government of Pakistan (2008), Economic Survey of Pakistan, Ministry of Finance, Islamabad, p. 216-217

Grasmuck, Sherri, and Rosario Espinal (2000) Market Success or Female Autonomy? Income, Ideology, and Empowerment among Micro-entrepreneurs in the Dominican Republic. Gender and Society, Vol. 14, No. 2 Pg. 231-255.

Heen, Stacy Michelle (2004), Microfinance and Conflict: Toward a Conflict-Sensitive Approach, The Fletcher School, p. 2

Musharaf, S. (2002), Pakistan Support Micro-credit Campaign, Tuesday November 12, 2002, THE NEWS, Pakistan.

Pakistan Microfinance Review (2006), and Performance Indicators Report (2005), Pakistan Microfinance Network, Islamabad.

State Bank of Pakistan (2005), The State of Pakistan's Economy; First Quarterly Report for FY05, pp.105-112.

Tessie Swope (2005), Microfinance and Poverty Alleviation, Independent Study May 2005. Pg. 3 
UNDP (2009), Human Development Index, Human Development Report 2009, UNDP available at; http://hdrstats.undp.org/en/countries/country fact sheets/cty fs PAK.html

Younus (2006), Paving the Way out of Poverty, Time Magazine, October 13, 2006.

Yunus, Muhammad (2004), Grameen Bank at a Glance, January 2004, www.grameeninfo.org/bank/GBGlance.htm

Prof. Dr. Shafiq-ur-Rehman is Chairman in the Department of Economics, University of Karachi.

Rizwana Bashir is Ph.D fellow in the Department of Economics, University of Karachi.

Adeela Sajjad is Ph.D fellow and visiting Lecturer in the Department of Economics, University of Karachi. 